\title{
Ser negro no Brasil: alcances e limites
}

\author{
FÁTIMA OLIVEIRA
}

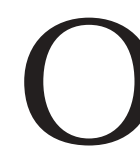

BRASIL É U M PAís mestiço, biológica e culturalmente. A mestiçagem biológica é, inegavel mente, o resultado das trocas genéticas entre diferentes grupos populacionais catal ogados como raciais, que na vida social se revelam também nos hábitos e nos costumes (componentes culturais). N o contexto da mestiçagem, ser negro possui vários significados, que resulta da escolha da identidade racial que tem a ancestralidade africana como origem (afro-descendente). O u seja, ser negro, é, essencialmente, um posicionamento político, onde se assume a identidade racial negra.

I dentidade racial/ étnica é o sentimento de pertencimento a um grupo racial ou étnico, decorrente de construção social, cultural e política. O u seja, tem a ver com a história de vida (socialização/ educação) e a consciência adquirida diante das prescrições sociais raciais ou étnicas, racistas ou não, de uma dada cultura. Assumir a identidade racial negra em um país como o B rasil é um processo extremamente difícil e doloroso, considerando-se que os modelos "bons", "positivos" e de "sucesso" de identidades negras não são muitos e poucos divulgados e o respeito à diferença em meio à diversidade de identidades raciais/ étnicas inexiste. Desconheço estudos brasileiros consistentes sobre identidade racial/ étnica.

\section{As classificações raciais: alcances e limites}

Em 1775, J ohann Friedrich Blumenbach (1752-1840), alemão, fundador da Antropologia, determinou a região geográfica originária de cada raça e a cor da pele como elementos demarcatórios entre elas (branca ou caucasiana; negra ou etiópica; amarela ou mongólica; parda ou malaia e vermelha ou americana). No século XIX, foram agregados outros quesitos fenotípicos, como o tamanho da cabeça e a fisionomia. D esde Blumenbach, no entanto, a cor da pele aparece como um dado recorrente. Inferindo-se, daí, que, dos dados do fenótipo, isto é, das características físicas, a "cor da pele" éo que tem sido mais usado e considerado importante, pois aparece em quase todas as classificações raciais.

Para fins de estudos demográficos, no Brasil, a atual classificação racial do IBGE (Instituto Brasileiro de Geografia e Estatística) é a que é tomada como oficial desde 1991. Tal classificação tem como diretriz, essencialmente, o fato de a coleta de dados se basear na autodeclaração. $O$ u seja, a pessoa escolhe, de um rol de cinco itens (branco, preto, pardo, amarelo e indígena) em qual deles se 
aloca. Como toda classificação racial é arbitrária e aceita não sem reservas, a do IBGE não foge à regra, pois possui limitações desde 1940, quando coletou pela primeira vez o "quesito cor" * . Sabendo-se que raça não é uma categoria biológica, todas as classificações raciais, inevitavelmente, padecerão de limitações. Todavia, os dados coletados pelo IBGE, ao reunir informações em âmbito nacional, são extremamente úteis, pois apresentam grande unidade, o que permite 0 estabelecimento de um padrão confiável de comparação.

O IBGE trabalha então com o que se chama de "quesito cor", ou seja, a "cor da pele", conforme as seguintes categorias: branco, preto, pardo, amarelo e indígena. Indígena, teoricamente, cabe em amarel os (populações de origem asiática, historicamente catalogados como de cor amarela), todavia, no caso brasileiro, dada a história de dizimação dos povos indígenas, é essencial saber a dinâmica demográfica deles. U m outro dado que merece destaque é que a população negra, para a demografia, é o somatório de preto + pardo. Cabe ressaltar, no entanto, que preto é cor e negro é raça. N ão há "cor negra", como muito se ouve. $\mathrm{H}$ á cor preta. A pesar disso, em geral, os pesquisadores insistem em dizer que não entendem, mesmo com a obrigatoriedade ética de inclusão do "quesito cor" como dado de identificação pessoal nas pesquisas brasileiras desde 1996, segundo a Resolução 196/ 96. N ormas de Ética em Pesquisa Envolvendo Seres H umanos (VI. Protocolo de pesquisa. VI. $3^{\prime}$ - informações relativas ao sujeito da pesquisa [...] cor [ classificação do IBGE]).

\section{$A$ identidade racial/ étnica}

De acordo com a convenção do IBGE, portanto, negro é quem se autodeclara preto ou pardo. E mbora a ancestral idade determine a condição biológica com a qual nascemos, há toda uma produção social, cultural e política da identidade racial/ étnica no Brasil.

Vale mencionar ainda as polêmicas sobre o conceito de raça e de etnia, que, grosso modo, raça deveria ser um conceito biológico, enquanto etnia deveria ser um conceito cultural. $\mathrm{N}$ ão sendo raça uma categoria biológica, etnia também se revela como um conceito que não é estritamente cultural, pois a delimitação de grupos étnicos parte de uma suposta alocação deles no conjunto dos grupos populacionais raciais sem abstrair a unidade do local de origem, e, para delimitar etnia, considera-se a conco mitância de características somáticas (aparência física), lingüísticas e culturais. Enfim, o conceito de raça é uma convenção arbitrária e pode ser enquadrada como uma categoria descritiva da antropologia, uma vez que é baseada nas características aparentes das pessoas. Portanto, o uso dos termos raça ou etnia está circunscrito à destinação política que se pretende dar a eles.

* Em 1940, o "quesito cor" era composto de: amarelo, branco e preto, mas havia o recurso para "cor indefinida" - que na tabulação dos dados foi denominada de "pardo" - o qual englobava: mulato, caboclo, moreno e similares que expressassem "nãobrancos" e não enquadrados como amarelo ou preto. 
Estudos da genética molecular, sob o concurso da genômica, são categóricos: a espécie humana é uma só e a diversidade de fenótipos, bem como o fato de que cada genótipo é único, são normas da natureza. Tendo o DN A como material hereditário e o gene como unidade de análise, não é possível definir quem é geneticamente negro, branco ou amarelo. 0 genótipo sempre propõe diferentes possibilidades de fenótipos. 0 que herdamos são genes e não caracteres!

Se para as ciências biológicas raça não existe e é consensual nas ciências sociais que o conceito de raça está superado, por que a insistência, em particular do movimento negro, em usá-lo como um paradigma da luta contra a opressão de base racial/ étnica, ou seja, do racismo? Por questões políticas, já que o racismo existe e é uma prática política que tem por base não apenas a existência das raças, mas que as "não-brancas" são inferiores.

\section{Políticas de ação afirmativa segundo sexo/ gênero e raça/ etnia}

A alocação das pessoas segundo classe social, sexo/ gênero e raça/ etnia se constitui em indicadores que podem ser traduzidos em políticas públicas antidiscriminatórias na área da saúde, da educação, do saneamento, da habitação, da segurança etc. U m exemplo paradigmático é dado pelo Dossiê "Assimetrias raciais no brasil: alertas para a elaboração de políticas", publicado pela Rede Feminista de Saúde e elaborado pela pesquisadora W ânia Sant'Anna (2003). E ste Dossiê promove um diálogo entre dados com recorte racial/ étnico nas mais diferentes áreas da vida so cial, sistematizados pelo I pea e obtidos das PN AD s da década de 1990 até 2001, além dos M egaobjetivos do "Plano Plurianual (PPA) 2004-2007 - O rientação estratégica de governo, um Brasil de todos: crescimento sustentável, emprego e inclusão social". O referido D ossiê visibiliza a crueza da realidade vivenciada pela população negra, uma situação de desvantagens e vulnerabilidades em todas as efferas da vida (disponível em <www.redesaude. org.br/ dossies/ html/ dossieassimetriasraciais.html).

A medicina baseada em evidências demonstra que algumas doenças são mais comuns ou mais freqüentes, ou evoluem de forma diferenciada, em determinados agrupamentos humanos raciais ou étnicos, conforme determinadas interações ambientais e culturais com o patrimônio genético. Relembrando que humanos são seres biológicos regidos também por leis biológicas, urge considerar que há uma produção social da enfermidade, ou da manutenção da sanidade, nas condições das sociedades de classes, da opressão racial/ étnica e da opressão de gênero. Diante do exposto, o significado político de se dar visibilidade aos dados da morbidade e da mortal idade segundo sexo/ gênero e raça/ etnia éincomensurável.

No caso da população negra, há vários estudos que corroboram que o recorte racial/ étnico na saúde é um componente essencial para a compreensão do que chamamos predisposição biológica, a qual, como tenho afirmado em vários escritos, significa a maior ou a menor capacidade de um ser vivo responder 
às complexas interações solicitadas pelo meio ambiente físico, e, no caso de humanos, também pelo meio ambiente cultural em que vive. A predisposição biológica resulta e refere-se a um longo processo evolutivo da humanidade, é o binômio indissociável: constituição hereditária + meio ambiente. 0 que quer dizer que o caráter social e histórico das doenças é amplamente demonstrado através da história de vida das pessoas, e esta está intimamente vinculada ao sexo (ao privilégio ou desprivilégio de gênero); à raça/ etnia (à vivência ou não do racismo).

A pesar das limitações inerentes ao que se convenciou denominar de classificação racial, é de grande valia uma classificação racial como a brasileira, pois através dela é possível delimitar de que adoece (morbidade) e de que morre a população negra, indicadores fundamentais para políticas de combate ao racismo institucional no aparelho formador, nas instituições e profissionais de saúde, sendo o mesmo válido para outras áreas.

RESUMO - O ARTIGO aborda a mestiçagem, a condição de afro-descen dência e a classificação racial oficial do Brasil (IBGE), além de tecer breves considerações sobre os conceitos de raça e de etnia; identidade racial/ étnica; e políticas de ação afirmativa segundo sexo/ gênero e raça/ etnia. Conforme convenção do IBGE, no Brasil, negro é quem se autodeclara preto ou pardo, pois população negra é o somatório de pretos e pardos. Para fins políticos, negra é a pessoa de ancestralidade africana, desde que assim se identifique.

\begin{abstract}
THIS ARTICLE deals with mixed ancestry, the condition of afro-descent and the official classification of races in Brazil, and includes brief considerations on the concepts of race and ethnicity, on racial/ ethnic identification, and on sex/ gender- and race/ ethnicity-specific affirmative action policies. According to convention adopted by the Brazilian Institute of Geography and Statistics (IBGE), a black person in Brazil is anyone who claims to be black or brown, inasmuch as the black population is deemed as the sum total of all blacks and mulattos. In political terms, a black person is anyone of African descent who identifies him/ herself as such.
\end{abstract}

Fátima Oliveira é médica, secretária executiva da Rede Feminista de Saúde (2002-2006) e presidenta da Regional M inas Gerais da Sociedade Brasileira de Bioética. Autora de: Engenharia genética: o sétimo dia da criação (M oderna, 1995); Bi oética: uma face da cidadania (M oderna, 1997); O ficinasmulher negra esaúde( M azza, 1998); Transgênicos: o direi to desaber ea li berdadedeescol her ( $M$ azza, 2000); 0 "estado da arte" da reprodução humana assistida em 2002 eC lonagem emani pula ação genética humana: mitos, realidade, perspecti vasedelírios (C N D M / M J , 2002); e Saúdeda populaçãonegra, Braśl 2001 (O M S/ O pas, 2002).

Texto recebido e aceito para publicação em 23 de fevereiro de 2004. 